\title{
Looking back again and forward
}

\section{Re: review and reconstruction in writing and architecture}

\begin{abstract}
The review in its multiplicity of forms and directions can be said to underpin architecture, crucially for its dissemination. From the perspective of a writer in and of architecture, the review is a means of both responding to the physical and of creating another form on the page. This piece focuses mainly on writers whose work moved from print to physical architecture: Walter Besant and Orhan Pamuk. It stresses the importance of 'looking again' in relation to forms of architectural review, from the ambulatory glance to the indepth reflection, through an array of examples including the "artefactual" and archi-fiction, manifesto, monograph, still and moving image. Revisiting the review encompasses notions of paper architecture, reconstruction, scale, weight and titles. It demonstrates how the review, and the process of looking again, covers the building or book itself and also, unavoidably, revisiting the historical and political and personal narratives attached to it.
\end{abstract}

Keywords: Writing, paper architecture, narrative, reconstruct, artefactual Subject classification codes: include these here if the journal requires them

About that ... hmmm ... Heard it all before? ... Take another look ...

To begin with an unpicking of "review" in relation to architecture: a review is a transposition involving critical response of some aspect from book to journal or from building to book. It is at once looking back and looking forward: what has happened and what may happen in the future. In the repetition, the original - book or building can never be experienced in the same way, once looked at again or revisited in terms of time or space. The distance, on whatever gauge, makes it impossible. Books and their reviews are enmeshed, knotted even, into architectural culture - as inspiration 
and collaboration with architecture's various productions and practices; even a level of conspiracy may be suspected in some cases. This brief exploration of some of the plethora of forms a review in architecture may take also engages with the multiplicity of possible directions and purposes.

The frequency with which words with the prefix re- (reuse renew regeneration redevelop revive recover renovate represent repurpose relocate renaissance and so on, to list but a few) are used in relation to aspects of architecture and related practices led to a brief etymological enquiry. The overarching sense of this taxonomy of re- is of "both again and take away" and "back to the original place, again," with a sense of redoing and undoing, so a repetition of the same thing and of its opposite. ${ }^{1}$ As this suggests, there is a certain circularity in play in the culture of the book review, as with the review of an example of architecture; and in both cases, there can be sustained critique, a brief ambulatory glance, leading to a re-examination.

As a writer in and of architecture, I take the book review, like the book, as another form of paper architecture, along with drawings and models. While the review suggests a revisit, paper architecture is another way of making architecture exist: writing it, as well as writing about it. Paper architecture in the form of writing can equally be put to work in the service of regeneration or in newbuild projects. In both cases this involves looking at what exists already and what, speculatively, could exist, so introducing elements of the fictional or "factish." "Paper architecture" is sometimes used as a perjorative term, its works dismissed in part because unbuilt,

${ }^{1}$ In relation to the review's capacity to unsettle a previously held opinion, it is interesting to note that this 'back and again' dynamic is similar to that present in the uncanny. With its movement between the familiar and the strange has some parallels to the idea of the review, returning to a work, textual or physical, that is known on some level in order to know more, or to know differently. 
therefore untested, or as visionary and impractical (as surely all architecture and innovation is at some point), even though architecture is necessarily about looking to the future, at the very least in terms of use.

Paper architecture has had some highly credible applications within the profession, as a material of protest and rescue. In the 1980s the Moscow practice Paper Architects worked in paper - and clearly wrapped themselves in it - to mark their opposition to government restrictions on architects' work and object to the lack of care for users demonstrated in the refusal to employ skilled workers, poor space standards and budget limitations. ${ }^{2}$ Shigeru Ban's work contributing to recovery after the Kobe earthquake in 1995 used 3D-printed paper buildings, which were also used post-earthquake in Haiti in 2010. More currently, post-disaster/atrocity ${ }^{3}$ commentary that features Grenfell Tower in west London makes it possible to be able to look again at both building and situation, to be thoughtful and informed about its implications for architecture more widely; even to examine images of it without overwhelming distress.

... Let's go over it again ... Same old story? ... Time to brush up on that ...

Varying the direction of the exchange, now the focus shifts on to other forms of review, some inverted from the more usual direction of writing responding to architecture. All of these examples are also ways of disseminating architecture through various versions and forms, and of reaching different audiences and readerships. Firstly, there is what is sometimes referred to as "archi-fiction." These

${ }^{2}$ And this is clearly another, unwanted, form being revisited.

${ }^{3}$ The fire at Grenfell Tower in west London in 2017 is now called an atrocity in some descriptions to draw attention to its avoidable nature. "The Tower" by Andrew O'Hagan in London Review of Books (7 June 2018) offers an indepth review of what happened to a building, the people and the media coverage. 
are novels that look again to architecture to provide a location, to set a specific stage for the narrative, adding some notion of authenticity (this is real!) and importance (this is a highly significant building!). Basing the fictional on fact in this way is an instance of what has become known as the "artefactual."

As a strand of architectural or urbanist writing, this lays a critical/cultural foundation on which to project a "factish" narrative. Mies's Tugendhat house (1928) in Brno (then Czechoslovakia, now Czech Republic) provides more than a location for Simon Mawer's The Glass Room (2010). ${ }^{4}$ Rather than serving as a mere backdrop, history and politics are acted out there - the development of modernist architecture, the advancement of the forces of Nazism and Communism, the Holocaust - alongside a fictional narrative about a Jewish Czech couple and their dreams for their domestic life. The Tugendhats who commissioned Mies to design the house were also a Jewish couple, but escaped the country in 1938. Christodora, a 1920s settlement house in New York, plays a similar role in Tim Murphy's novel of the same name (2017), in which it offers a foundation for a narrative detailing some of the gentrifying effects of regeneration in the East Village. ${ }^{5}$ Set in the 1980s, Christodora traces the effects of the Aids epidemic along with the development of the city, of a particular moment of intertwined arts practice and activism in ACT UP, and attitudes to and treatments for addiction. Will Self's Umbrella (2012) is also set in a neighbourhood building, Friern Barnet mental hospital in north London, famously endowed with the longest corridor in the country. ${ }^{6}$ Here, the hospital (aka Colney Hatch), which occupies much space in local stories, provides an example of building-as-character.

\footnotetext{
${ }^{4}$ Simon Mawer, The Glass Room (London: Abacus, 2010).

${ }^{5}$ Tim Murphy, Christodora (New York, NY: Grove Press/Atlantic Monthly Press, 2016).

${ }^{6}$ Will Self, Umbrella (London: Bloomsbury, 2012).
} 
Secondly there are books from other disciplines that regularly feature on architecture reading lists, whether in academic or media contexts ("The ten books everyone interested in architecture must read" etc). Among these, works by Italo Calvino, W G Sebald and Ayn Rand are frequent mentions. ${ }^{7}$ Some of these, works from related disciplines, can be used as a means of reviewing architecture. These range from the more obvious photography and film works, such as work by photographers Hélène Binet or Bas Princen or, for example, Steven Jacobs’ The Wrong House: The Architecture of Alfred Hitchcock to Erik Larson's architecture and serial killer thriller, Devil in the White City: Murder, Magic, and Madness at the Fair That Changed America (2003). ${ }^{8}$ Larson's book is a clear example of the artefactual, based on the Chicago Fair of 1893. It reads like a novel and provides a striking portrait of the development of modern architecture in the US. In so doing it brings the work of Frederick Olmsted, Daniel Burnham, Charles McKim and Louis Sullivan to the attention of an audience who may be more attracted to the exploits of $\mathrm{H} \mathrm{H}$ Holmes, the serial killer and his extraordinary, murderous house-of-horror designs. And this also operates in reverse.

Thirdly, and most significantly for this re:review, from another direction again, there are the examples of architecture where the design has involved looking

${ }^{7}$ Some examples: Italo Calvino, Six Memos for the Next Millennium (Harmondsworth, UK: Penguin Classics, 2016); Invisible Cities (San Diego, CA: Harcourt Brace \& Company, 1978); W G Sebald, The Emigrants (London: Vintage Classics, 2002; Austerlitz (London: Penguin Books, 2001); Ayn Rand, The Fountainhead (Indianapolis, IN: Bobbs Merrill, 1943).

${ }^{8}$ Hélène Binet and Mark Pimlott, Composing Space: The Photographs of Hélène Binet (London: Phaidon, 2012). Bas Princen, Reservoir (Berlin: Hatje Cantz, 2011). Steven Jacobs, The Wrong House: The Architecture of Alfred Hitchcock (Rotterdam: 010 Uitgeverij, 2007). Erik Larson, Devil in the White City: Murder, Magic, and Madness at the Fair That Changed America (Crown Publishing, 2003). 
again at a book and then away from it to produce something else. This might be described as the building itself as a book review. Two literal examples in the public sphere that emanate from revisiting - reviewing in a sense - a book, come from Walter Besant, All Sorts and Conditions of Men: an Impossible Story (1882), and Orhan Pamuk, The Museum of Innocence (2008). ${ }^{9}$ In both cases, the building operates as a response to the book, making something of it, critiquing and appraising it, even demonstrating how it can work in another context. Further down this chain, when reviewing the resulting building it can make sense to return again to the original book itself, as source material for that review in turn.

Walter Besant provides an excellent example of a writer concerned to contribute to architecture as well as writing about it. He produced work on a "palace of the people" in criticism, fiction and built form. In All Sorts and Conditions of Men, Besant writes a fictional construction - at once critical, satirical and speculative - of a people's palace, a place of entertainment and education and leisure, which recounts the development of this wondrous building in a poor area of London. The novel may have been the dry (certainly droll) run: Besant then instrumentalized his writing by contributing to the design of such a building by architect E R Robson (1887) in Mile End in east London. From its (strangely modern) position of building as character in a novel, it becomes, eventually, novel-as-building, and part of Queen Mary College, University of London. ${ }^{10}$

\footnotetext{
${ }^{9}$ Walter Besant, All Sorts and Conditions of Men: an Impossible Story (London: Chatto \& Windus, 1882). Orhan Pamuk, The Museum of Innocence (London: Faber \& Faber, 2008).

${ }^{10}$ Reviewing the building, its purpose and programme, continues: this 'people's palace' is now part of Queen Mary College's hospitality suite, and so is inaccessible to 'the people' for whom it was originally envisaged without tickets or passes.
} 
Taking a (very unmodern) reading of the experience recounted in the novel as authorial position, it seems Besant was aware of the complexity of the project of founding a people's palace, built or written. The novel's subtitle (the "Impossible Story" - a real fiction) could stand as a warning against building another iron-andglass exhibition hall after the Great Exhibition building (1851) in Hyde Park. In conjunction with his writing on the subject in Contemporary Review, it suggests that Besant took notice of falling visitor numbers there. ${ }^{11} \mathrm{He}$ understood that an attempt to reiterate it and reprise its success would not work, at least not without some consultation with its intended users and serious consideration of their means. ${ }^{12} \mathrm{He}$ is then reviewing this building in his fiction and critical writing as well as perhaps (p)reviewing his own.

Angela, the novel's protagonist, may be Besant's alter-ego too, saying what he couldn't or had learned not to say:13 “' Ah!' cried Angela, with a sigh. 'The Palace of Delight: the Palace of Delight: we must have it: if it is only to make the people discontented." 14 This quotation gestures to an understanding of "the palace's" position as both an impetus for change and because "the people" would soon outgrow it. Seeing its limitation and realising what has been denied them, they will, Angela intimates, demand more - ambition will almost immediately outgrow what is possible. There is no knowing whether Besant was aware or hopeful that his novel, the

\footnotetext{
${ }^{11}$ Walter Besant, “The People's Palace," The Contemporary Review, 1 January 1887. 226-33.

${ }^{12}$ These important considerations went unheeded by those involved in building Alexandra Palace, north London - another people's palace and one whose fortunes Besant may have been satirising in the novel.

${ }^{13}$ That said, her hilarious pomposity and limited self-awareness light up the novel, although this reader wonders if it should also be taken as scorning a woman's audacity for taking on such a project.

${ }^{14}$ Op cit. 1887:vol.1:313
} 
fictional construction, would operate as research, programming and plan for the building, or even if he saw it like that afterwards. Perhaps it is only the benefit of 150year hindsight that makes this causal link so clear and strong. His efforts to put the putative users first by asking them about what they wanted in their palace were successful only in the short-term. In terms of review, it is useful to revisit the changing understandings of "people" and "public" in the era of the "publiod" (coined by Rowan Moore in Slow Burn City, 2017) or pseudo-public, over-regulated spaces, and the idea of user engagement and consultation within redevelopment and regeneration. ${ }^{15}$

In its movement from the textual to the physical, the various iterations of Orhan Pamuk's Museum of Innocence are further inspiring examples of writing the building, a contemporary version of this novel-to-building process and back again. ${ }^{16}$ This multi-form work existed originally as literature and building, which the author conceived together, as complementary works and process, although the novel was published two years before the museum opened in Istanbul. The museum is described as a companion piece to the novel, as a reversioning of the novel in physical form. In this sense the museum is then perhaps only a review for the reader/visitor, who looks at the new form differently, experiences and absorbs it over different time. It was later produced as a film, Innocence of Memories, directed by Grant Gee (2015) and then also as an exhibition, as an installation of the museum (Somerset House, January 2016) incorporating aspects of all three manifestations. ${ }^{17}$ Pamuk studied architecture

\footnotetext{
${ }^{15}$ Rowan Moore, Slow Burn City (London: Picador, 2017).

${ }^{16}$ Orhan Pamuk, The Museum of Innocence (London: Faber \& Faber, 2010).
}

${ }^{17}$ Grant Gee, dir., Innocence of Memories (UK, 2015); Museum of Innocence, exhibition, Somerset House (London, January 27-April 3, 2016). 
himself but the name of the museum's designer is well hidden - similarly, it takes some time to discover the name of the architect of "Besant's" palace. In this instance, the instigator of the project, who was not its funder, is the name attached.

The museum was funded by the money Pamuk received as a Nobel prizewinner. In the novel, the museum was to be funded by the wealth of the protagonist, Kemal, but it is given life on the page by the meticulous rendering of Kemal's fantasy of memorializing his love for Füsun and his lost paradise of their days together. In this space he would be able to display every little thing that he has managed to steal that Füsun has touched, when he couldn't touch her. Items like a hairslide, a salt pot, a china dog eventually find their home in that museum of the novel's title, a shrine to everyday life that Kemal will spend his last years in building. Versions of them, including a vitrine of the cigarette butts Füsun smoked in his presence, are housed at the actual museum in Istanbul along with a collection of items that would, in the time of the novel, have been seen as modern appliances, new desirable inventions, only to be quickly discarded.

Through his work Pamuk speaks out for stories about the small and local, about houses not monuments, causing the reader to, again, review the individual and personal form against the official or governmental. He chose to redevelop a residential dwelling for his museum of innocence. Yet in reviewing his novel through architecture he has to some extent created a monument himself: to this process, to his work and to Turkey's struggle with modernity, in terms of urbanism, culture and architecture. This house is now a monument to Pamuk himself and to his novel, and also to the desperate love of Kemal, and to Faisal, the largely unwilling recipient and object of this love. 
So is Pamuk then talking about scale? He might be suggesting that it is the story of the "ordinary person," not the person that a government has chosen to memorialize that is most worthwhile or of use or believable. Yet monuments as well as domestic houses have meaning for ordinary people. They are structures that ordinary people have built, sometimes contributed to through subscription, walked past, sat upon, become meeting points and landmarks.

Taking stock ... I need you to revisit ... Come again?

In mentioning scale, it is also instructive to consider the physicality of the formats: the heft of the book as against the lightness of the review. Physically, at least, the review can never be as weighty as the original. Newly published hardbacks (too expensive to buy) are borrowed gratefully from libraries although sometimes too heavy to prop up in bed or to carry on transport. The review, in print, generally appears in a physically light-weight journal or magazine. Then there is the use of the pamphlet or chap book, often responding to a single event or publication, or on a single theme. These are nimble, inexpensive forms, easy to distribute, theoretically at least. ${ }^{18}$ Online or ereader versions can have added uses, for example as teaching preparation aids, with links for further research, for taking notes and so on but for some readers the lack of the texture and substance of the paper version outweighs any benefits. This corresponds to some of the differences between reviewing architecture through images or in physical form.

On levels other than the literal, reviewing work, their own and others' has proved useful for architects themselves, as a good way of garnering attention, in

\footnotetext{
${ }^{18}$ Now popular in festivals or biennales but the realities of the book trade make distribution, and therefore sales of material departing from standard book forms unlikely through shops.
} 
launching careers or projects. Architects such as Le Corbusier and Rem Koolhaas famously made weighty declarations of intent through the use of the review and of the book before reconsidering and reproducing their ideas in architectural form. When Corb co-founded L'esprit nouveau he not only had not built anything, he also did not yet have his name: he was still known then as Charles-Edouard Jeanneret. ${ }^{19} \mathrm{He}$ reviewed the material in the magazine, it might be said, to then produce his book or manifesto, Five Points Towards a New Architecture in 1926, by then equipped with his reinvention of himself through his nom de plume or pseudonym. ${ }^{20}$ Koolhaas, perhaps learning from how Corb had used books as provocative tools to establish himself, produced Delirous New York: A Retrospective Manifesto for Manhattan in 1978 - an example of a book reviewing a city for the future, looking forward and back. ${ }^{21}$ Looking again at Koolhaas's titles, in other cases too they can be read as provocations, so in the case of $S M L X L$, it is all about size (my words weigh like a building), whereas with Content, it is nothing to do with form. ${ }^{22}$

\section{Revisiting ... Refresh the page ... Refresh the page}

To finish with a book review in miniature scale, in yet another approach to the review, there is the deliberate return to a book. ... You remember enjoying it, but not why exactly. You think you're coming home but you've been away, things have changed, you have moved on, time has passed, attitudes have changed ...

\footnotetext{
${ }^{19}$ Charles-Edouard Jeanneret and Amédée Ozenfant, eds, 1920-25, L'esprit nouveau.

${ }^{20}$ Le Corbusier, Five Points Towards a New Architecture (Paris: 1926).

${ }^{21}$ Rem Koolhaas, Delirious New York: A Retroactive Manifesto for Manhattan (New York: Oxford University Press, 1978).

${ }^{22}$ Rem Koolhaas, Content (Cologne, Germany: Taschen, 2004); SMLXL (New York, NY:
} Monacelli Press, 1995). 
This re:view now moves from Pamuk's house to House by Tracy Kidder, to see what it looks like from here, in terms of time, attitude, perspective and other shifts that have taken place. ${ }^{23}$ This is an architecture book with less than a handful of images, line drawings and elevations-as-blueprint segments for chapter openers. House, this time around, still reads like fiction, which seemed revelatory twenty or so years ago on first reading. Again the title reverberates. This time around it is the question of the missing article and why this is engaging and attractive. Why "house" not "the house" or "a house"? It is both a highly personal portrait of a house and not, almost archetypal, any house, all the houses. Yet it couldn't be more individual, already belonging to the Souweines, and now through the works described in the book will become even more and completely and always theirs: all their houses come at once.

Additionally, its appeal now is in its presentation of a kind of review, an interesting and unusual critique of architectural process and the roles within it. The narrative of the ordinary person has often, historically, been missing from architecture - judged insignificant from serious consideration (outside perhaps, oral history and cultural studies, community-based projects). The user is largely absent and so too is the builder. The work is done or not, carried out to schedule or not, to the standard set by the developer, the funder, according to the design of the architect. Builders are bitparts, often depicted as obstructions in terms of time, attitude, skills and so on. What stands out too, reviewing House now, is how it seems to function as a disquisition on relationships and negotiations between client and builders, while the architect has a fairly minor role confined to the early stages and largely forgotten as the narrative

\footnotetext{
${ }^{23}$ Tracy Kidder, House (Boston, MA: Houghton Mifflin, 1985).
} 
progresses. Here the builders are craftsmen and are as embedded in the locality as the house and the client. Other characters radiate out from them, even though each element has their own section/chapter/turn as narrator. House is structured, as classical drama, into five acts of the project: The contract, Architecture, Wood, In a workmanlike manner, Returns.

Returns. And so back and again. Whether the Tugendhat house, the house of the museum, the Souweines' house, or one of the apartments at Christodora, the house embodies events of its time, of its inhabitants' lives and of the wider world in one of its multiple directions. The architecture offers a site through which to review the historical and the contemporary, and of the reviewer or "revisitor's" time, to look back and look again.

Step back and again ... re:review ...

\section{References}

Besant, Walter. 1882. All Sorts and Conditions of Men. An Impossible Story. London: Chatto \& Windus.

1887. “The People's Palace.” The Contemporary Review. 1 January. 226-33. https://hullhouse.uic.edu/hull/urbanexp/main.cgi?file=viewer.ptt\&mime=blan $\mathrm{k} \& \mathrm{doc}=462 \&$ type $=$ print [accessed June 2018]

Binet, Hélène and Mark Pimlott. 2012. Composing Space: The Photographs of Hélène Binet. London: Phaidon.

Calvino, Italo. 2016. Six Memos for the Next Millennium.Harmondsworth, UK: Penguin Classics.

1978. Invisible Cities. San Diego, CA: Harcourt Brace \& Company.

Le Corbusier. 1926. Five Points Towards a New Architecture.

Gee, Grant, director. 2015. Innocence of Memories. UK.

Jacobs, Steven. 2007. The Wrong House: The Architecture of Alfred Hitchcock.

Rotterdam: 010 Uitgeverij. 
Jeanneret, Charles-Edouard [Le Corbusier] and Amédée Ozenfant, eds. 1920-25. L'esprit nouveau. Paris.

Kidder, Tracy. 1985. House. Boston, MA: Houghton Mifflin.

Koolhaas, Rem. 2004. Content. Cologne, Germany: Taschen. 1995. SMLXL. New York, NY: Monacelli Press.

1978. Delirious New York: A Retroactive Manifesto for Manhattan. New York: Oxford University Press.

Larson, Erik. 2003. Devil in the White City: Murder, Magic, and Madness at the Fair That Changed America. Crown Publishing.

Mawer, Simon. 2010. The Glass Room. London: Abacus.

Moore, Rowan. 2017. Slow Burn City. London: Picador.

Murphy, Tim. 2016. Christodora. New York, NY: Grove Press / Atlantic Monthly Press.

O’Hagan, Andrew. “The Tower.” London Review of Books. June 7, 2018.

Pamuk, Orhan. 2010. The Museum of Innocence. London: Faber \& Faber.

Princen, Bas. 2011. Reservoir. Berlin: Hatje Cantz.

Rand, Ayn. 1943. The Fountainhead. Indianapolis, IN: Bobbs Merrill.

Sebald, W G 2002. The Emigrants. London: Vintage Classics. 2001. Austerlitz. London: Penguin Books.

Self, Will. 2012. Umbrella. London: Bloomsbury. 